DOI: https://doi.org/10.47405/mjssh.v6i7.852

\begin{tabular}{|c|c|}
\hline 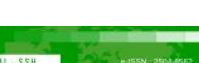 & Malaysian Journal of Social Sciences and Humanities (MJSSH) \\
\hline Malaysian Journal of & Volume 6, Issue 7, July 2021 \\
\hline (MJ-ssH) & e-ISSN : 2504-8562 \\
\hline & $\begin{array}{l}\text { Journal home page: } \\
\text { www.msocialsciences.com }\end{array}$ \\
\hline
\end{tabular}

\title{
Peranan Kepimpinan Distributif dalam kalangan Pemimpin Pertengahan dan kesannya ke atas Komitmen Organisasi dan Iklim Sekolah: Suatu Tinjauan Awal
}

\author{
Norliza@Noriza Ahbar@Akhbar1, Rosnah Ishak¹, Jamal@Nordin Yunus1 \\ 1Fakulti Pengurusan dan Ekonomi Universiti Pendidikan Sultan Idris (UPSI) \\ Correspondence: Norliza@Noriza Ahbar@Akhbar (norlizaakhbar@yahoo.com)
}

\begin{abstract}
Abstrak
Kepimpinan distributif dikatakan masih kurang dijalankan penyelidikannya di Malaysia terutama bagi kalangan pemimpin pertengahan. Kajian-kajian lepas didapati lebih merujuk kepada amalan kepimpinan distributif di kalangan pengetua ataupun guru besar, justeru kajian tinjauan awal ini bertujuan untuk mengenal pasti keberkesanan kepimpinan distributif di kalangan pemimpin pertengahan terutamanya di kalangan Penolong Kanan Pentadbiran serta kesannya terhadap komitmen organisasi dan iklim sekolah. Tinjauan awal ke atas sumber literatur mendapati bahawa terdapat perkaitan jelas antara kepimpinan distributif pemimpin pertengahan dengan komitmen guru dan iklim sekolah.
\end{abstract}

Kata kunci: kepimpinan distributif, pemimpin pertengahan, komitmen guru, iklim sekolah

\section{The Role of Distributive Leadership in Middle Leaders on Teacher Commitment Organization and School Climate: A Preliminary Observation}

\begin{abstract}
The distributive leadership, especially among middle leaders is said to be under researched in Malaysia. In previous studies, it referred more to distributive leadership practices among principals or headmasters, therefore this preliminary survey aims to identify the effectiveness of distributive leadership among the middle leaders, especially Senior Administrative Assistants. It also focus on its impact on organisational commitment and school climate. A preliminary review of literature sources found that there was a clear correlation between the distributive leadership of middle leaders with teacher commitment and school climate.
\end{abstract}

Keywords: distributive leadership, middle leaders, organisation commitment, school climate

\section{Pengenalan}

Persepsi mengenai kepemimpinan pada era 90-an merupakan kepemimpinan yang tiada tandingan, berkarisma dan memfokuskan sifat dan tingkah laku pemimpin tunggal (Bass \& Riggio, 2008; Pearce \& Manz, 2005; Pearce \& Sims, 2002; Yukl, 1999). Pemimpin ketika itu dikenali sebagai orang utama 
yang meneraju pengikut (didefinisikan sebagai orang bawahan) dalam organisasi. Dalam erti kata lain mempunyai perspektif bermula dari atas ke bawah. Kepimpinan dalam organisasi pendidikan masa kini tidak lagi hanya menjurus kepada Pengetua ataupun Guru Besar sebaliknya ia meliputi perkongsian kepimpinan bersama barisan penolong-penolong kanan dan guru-guru yang lainnya (Marlia \& Yahya, 2016).

Para pengkaji perihal kepemimpinan pendidikan terdahulu mendapati kecemerlangan sesebuah organisasi pendidikan adalah disebabkan faktor kepimpinan pendidikan (Harris, 2004; Hussein Mahmud, 1993; Hussein Ahmad, 2012; Leithwood \& Jantzi, 1999; Ofsted, 2000; Kementerian Pendidikan Malaysia, 2013; Sergiovanni, 2000). Danielson (2007) menyatakan sudah menjadi tradisi pemimpin sekolah akan memikul pelbagai cabaran dalam usaha berhadapan dengan perubahan organisasi dalam kancah pendidikan sebagaimana yang diharapkan oleh pihak atasan yang mempunyai kepentingan terhadap pembangunan pendidikan itu sendiri. Oleh sebab itu Harris (2002) berpendapat kepemimpinan pendidikan pada era ini lebih mengutamakan stail kepimpinan distributif yang lebih memberi fokus kepada pembentukan budaya akauntabiliti dalam melaksanakan tugas seterusnya membangunkan kompetensi kepemimpinan .

Hal ini terkandung dalam gagasan transformasi pendidikan pada Dasar Pelan Pembangunan Pendidikan 2013-2025 (PPPM 2013-2025) melalui anjakan yang kelima iaitu "Memastikan Kepimpinan Berprestasi Tinggi Ditempatkan Di Setiap Sekolah". Kualiti kompetensi kepimpinan baik dari pihak PGB, pemimpin pertengahan mahupun para guru dipercayai dapat menjurus kepada kemenjadian murid dan menjana pemikiran aras tinggi. Sesuai dengan corak pendidikan masa kini yang semakin mencabar dan menekankan pendidikan abad ke-21, kepimpinan distributif dikatakan kepimpinan berbentuk informal dengan mengadaptasi cara agihan tugas, saling mempercayai di kalangan ahli, rasa kebertanggungjawaban terhadap tugas seterusnya bergantung kepada hubungan yang ada (Azhar et al., 2016).

Secara amnya, gaya kepimpinan distributif mula adaptasi pada tahun 2000 dan mula dibangunkan dengan pesatnya pada tahun 2009. Bolden (2011) melalui laporan meta analisis yang dijalankannya mendapati gaya kepemimpinan distributif telah dikesan seawal 1250 BC dan ia digunakan secara relatif di kesemua negara dengan cara yang berlainan baik di sektor awam mahupun di sektor swasta. Menurut Harris dan Spillane (2008) hasil dapatan yang positif juga diterima daripada laporan meta analisis tersebut yang mendapati kepemimpinan distributif antara faktor yang menyumbang ke arah keberkesanan dan kemajuan sekolah dan telah disahkan dengan hasil dapatan oleh Harris dan Muijs (2004), Hulphia dan Devos (2009), Leithwood dan Jantzi (2000) serta Silins dan Mulford (2002) yang mendapati ada hubungan yang signifikan di antara kepemimpinan distributif dengan prestasi sekolah.

Namun terdapat juga kajian-kajian yang menunjukkan terdapatnya kelemahan pada kepimpinan distributif (Bolden, 2011). Antara faktor yang dikesan menyebabkan kelemahan tersebut adalah pengekalan struktur hierarki di sekolah (Louis et al., 2009). Hasil kajian oleh Newman dan Simmons (2000), Smith dan Piele (1997) serta Smylie \& Brownlee-Conyers (1992) menemui faktor kekeliruan terhadap tugas dan peranan di kalangan para pemimpin dalam sesebuah organisasi hingga menimbulkan konflik juga merupakan penyumbang kepada berlakunya kelemahan tersebut. Sekali lagi Bolden (2011) melalui analisis menggunakan meta analisis mendapati impak terhadap gaya kepimpinan distributif dan keberkesanannya juga adalah berhubung kait dengan aspirasi dan pengalaman oleh pengamalnya (Harris \& Spillane, 2008) manakala Gordon (2010) serta Woods dan Gronn (2009) mendapati pengaruh kuasa dan struktur sedia ada yang terbentuk di dalam sesebuah organisasi juga perlu diberikan pertimbangan dalam menentukan keberkesanan praktis kepemimpinan distributif dalam kalangan pemimpin khasnya.

Menurut Jaros (2010) dan Neves (2011) perspektif pendidikan masa kini menuntut daya saing hingga ke peringkat global justeru institusi pendidikan tidak dapat lari dari norma perubahan organisasi bagi meneruskan mahupun mengekalkan kejayaan. Faktor kepimpinan amat penting dalam membantu untuk mereformasi serta memperbaiki kualiti pendidikan bagi persaingan yang positif (Levin \& Fullan, 2008). Bagi memastikan perubahan yang positif berlaku di dalam organisasi pendidikan maka guru adalah individu yang berfungsi sebagai pelaksana utama, perlu memberikan komitmen dan 
tanggung jawab mereka sebagai inisiatif kepada perubahan instruksional seterusnya menjayakan reformasi dalam pendidikan.

Nilai tanggungjawab juga dilihat sebagai salah satu elemen yang penting dalam amalan kerjasama yang padu kerana para pengkaji mendapati ia mampu memberikan inspirasi terhadap iklim sekolah bersesuaian dengan situasi komuniti pembelajaran yang dilihat saban hari berdepan dengan cabaran serta pertambahan tugas-tugas seharian (De Matthews, 2014). Sekolah yang efektif dilihat dari kecenderungan pihak pentadbir meningkatkan pemerkasaan guru. Kajian mendapati pemerkasaan guru mempunyai hubungan yang positif dengan kualiti pengajaran dan inovasi, kepuasan kerja, kepemimpinan, komitmen guru dan organisasi sehingga memberi kesan positif terhadap peningkatan organisasi (Bogler \& Somech, 2004; Dee, Henkin \& Duemer, 2003; Erawan, 2008; Ghani, Hussin \& Jusoff, 2009; Lee et al., 2011; Muijs \& Harris, 2003; Short \& Rinehart, 1992; Wan, 2005; Zembylas \& Papanastasiou, 2005; Ai Noi \& Youyan, 2014).

Cohen et al. (2009) berpendapat pentadbir perlu menetapkan kesegeraan dan nada bagi program harian, menerajui warga organisasi dalam menyediakan visi untuk berjaya juga membuat rumusan disamping menjayakan rancangan bagi melaksanakan visi tersebut. Owens dan Robert (1991) dalam Agista (2018) pula menyatakan dalam mencapai peningkatan keberkesanan organisasi, para pentadbir seharusnya mampu mengupayakan iklim organisasi yang positif. Menurutnya lagi iklim organisasi merupakan kajian perihal tanggapan atau persepsi seseorang dari pelbagai sudut persekitaran yang membentangkan senario sistem dan nilai kepercayaan yang terdapat pada sesebuah organisasi.

Sementara itu Kelly et al. (2005) mendapati apabila seseorang pentadbir melakukan tindak balas yang betul mengikut keadaan maka persepsi guru terhadap iklim sekolah juga semakin tinggi. Persepsi guru ketika ini dianggp penting kerana ia bukan sahaja mengenai kepercayaan terhadap kepimpinan para pentadbir bahkan dapat membantu meningkatkan komitmen guru dalam meningkatkan prestasi kecemerlangan murid- murid. Penulisan ini dihasilkan merujuk kepada kajian-kajian berkaitan kepimpinan yang menjurus kepada kepimpinan distributif pemimpin pertengahan iaitu penolong kanan pentadbiran, komitmen guru dan iklim organisasi sama ada di dalam mahupun di luar Malaysia bermula dari tahun 2014 - 2020.

\section{Pemimpin dan Kepemimpinan}

\section{Definisi Pemimpin}

Istilah pemimpin membawa maksud individu yang mempunyai pengaruh atau kuasa di dalam sesebuah organisasi, tempat bekerja juga di dalam sesebuah kelompok manusia (Blandford, 2004). Menurut Bennis dan Nanus (1985), mereka mendefinisikan pemimpin sebagai individu yang dapat memberi rangsangan orang bawahan untuk melakukan tindakan, berupaya menjadikan pengikut sebagai pemimpin serta dapat menjadikan seorang pemimpin itu sebagai agen perubahan. Selain itu juga pemimpin dikatakan sebagai seseorang yang sentiasa melibatkan diri dalam apa jua bentuk situasi sama ada yang diketahui atau tidak diketahui malah mempunyai mesej dan visi yang mudah difahami dalam memastikan perkhidmatan teras dilaksanakan (Kouzes \& Posner, 2003). Bass (1990) pula berpendapat pemimpin mampu menjalankan tanggungjawab salah satunya seperti memimpin orang bawahan dalam melaksanakan sesuatu kerja dengan tujuan matlamat organisasi yang ditetapkan dapat dicapai.

\section{Definisi Kepemimpinan}

Menurut Fiedler (1967), Hollander (1979) dan Richard (2008), kepemimpinan didefinisikan sebagai hubungan antara individu perseorangan yang mempamerkan pengaruh juga kuasa yang dibahagikan secara tidak sama rata dengan maksud untuk mencapai matlamat organisasi melalui arahan dan 
kawalan tindakan ke atas orang lain. Bennis dan Nanus (1985), kepemimpinan juga dikatakan membawa maksud seperti yang dinyatakan di dalam tiga komponen berikut iaitu:

a. agen biasa yang dikenali sebagai pemimpin,

b. tingkah laku yang lahir dari pujukan seterusnya dikenali sebagai pengaruh,

c. kebolehan memanipulasi ataupun interaksi bagi memperoleh kuasa sebagai balasan.

Selain itu Stogdill (1990) berpendapat bahawa kepemimpinan adalah satu proses yang mampu mempengaruhi kegiatan-kegiatan ke atas sesuatu kumpulan atau kelompok manusia secara tersusun berpandu dalam menentukan matlamatnya.

\section{Kepimpinan Distributif}

Watson \& Scribner (2007) memberitahu bahawa teori kepimpinan distributif adalah lahir dari teori psikologi sosial apabila pemimpin yang mengamalkan kepemimpinan distributif menumpukan perhatian kepada paten interaksi antara staf di dalam organisasi. Melihat kepada skop ini maka kepemimpinan distributif disebarkan sebagai pengaruh interaksi dan sosial yang bertindak sebagai teras kepada amalan kepemimpinan. Proses itu juga dapat memudahkan perubahan tingkah laku berlaku dalam konteks sosial melalui interaksi yang dinamik di kalangan ahli organisasi Bandura, 1986). Menurut Hoy dan Miskel (2012), cetusan idea mengenai kepimpinan distributif dizahirkan apabila berlakunya rasa ketidaksanggupan dalam menghadapi pelbagai tugasan yang terlalu rencam dan rumit serta memikul tanggungjawab yang berat oleh seseorang pemimpin atau pentadbir secara solo.

Justeru, pembahagian tugas yang kompleks tersebut terpaksa dilakukan kepada beberapa orang individu dari kalangan staf organisasi. Spillane et al. (2004) menyatakan bahawa kepimpinan distributif adalah cara bagaimana seseorang individu menggembleng kepimpinan dengan menggunakan pendekatan interaksi dalam pelbagai aktiviti harian di dalam organisasi. Interaksi yang berlaku tertumpu kepada tiga elemen utama yang menjadi tunjang kepada semua aktiviti kepimpinan iaitu pemimpin, pengikut dan keadaan sebagai amalan dalam kepemimpinan. Harris (2012) berpendapat bagi institusi pendidikan guru-guru akan berkolaborasi secara berkumpulan menerusi bidang kepakaran masing-masing melalui aktiviti bekerjasama.

Halverson (2007) dan Malloy (2012) pula menyatakan skop kepimpinan ini bukan sahaja bekerjasama dan berinteraksi secara berkumpulan di antara mereka bahkan berkongsi matlamat yang sama bukannya secara individu. Para pengkaji mendapati kesan daripada perkongsian ini membentuk fenomena penglibatan guru dalam menjana keputusan seterusnya lebih ramai berperanan sebagai berkepimpinan bagi membentuk pasukan yang kuat dalam mencetuskan inovasi (Botha \& Triegaardt, 2014). Individu yang mengamalkan kepemimpinan ini adalah dari kalangan pelbagai pemimpin yang mempunyai kedudukan kepimpinan sama ada secara rasmi ataupun tidak rasmi (Spillane, 2006) berikutan kepemimpinan ini tidak mementingkan kedudukan hierarki sebaliknya kepada asas kepakaran kepimpinan seseorang pemimpin (Woods, 2004).

Bolden (2007) menghuraikan bahawa gaya kepimpinan distributif lebih merupakan tatacara pembahagian dan sebaran kepimpinan bukannya menambah jumlah bilangan pemimpin. Dinham et al. (2006) turut berpendapat bahawa kepimpinan ini berupa perwakilan tanggungjawab yang diberikan oleh seorang ketua kepada subordinat. Selain daripada membahagikan struktur bidang tugas kepemimpinan ini juga turut melibatkan elemen memperkasakan staf, menyokong, menggalakkan dan pembangunan. Spillane et al, (2004) menyatakan bahawa teori kepimpinan distributif terdapat pada pelbagai sumber yang mempunyai pengaruh di dalam sesebuah organisasi termasuklah budaya berkepimpinan bersama, kolaboratif dan penyertaan.

\section{Pemimpin Pertengahan}

Menurut Bush (2001), pemimpin pertengahan diertikan sebagai seseorang individu yang diamanahkan untuk menggalas tanggungjawab yang kritikal dalam memastikan keberkesanan perjalanan organisasi, menjalankan tugasan seharian dalam mengurus unit atau jabatan di samping menyebarkan sumber 
pengajaran dan pembelajaran. Mereka terdiri dari kalangan ketua-ketua jabatan bagi sesebuah mata pelajaran. Mereka lebih dikenali sebagai orang perantara yang mempunyai watak dalam meningkatkan mutu pendidikan di sekolah. Pemimpin pertengahan juga dilihat sebagai individu yang melibatkan diri secara langsung dalam program reformasi sekolah seraya mempamerkan kesungguhan yang tinggi dalam meningkatkan ilmu pengetahuan khasnya dalam mengadaptasi amalan-amalan kepemimpinan pengajaran serta komited dalam menolong para guru (Troen \& Boles, 1993).

Wise (2001) juga berpendapat bahawa pemimpin pertengahan didefinisikan sebagai orang kanan yang berperanan di sekolah dan pemimpin yang berpengaruh dalam memberi keputusan khasnya kepada sumber pengajaran dan pembelajaran, hal yang bersangkutan dengan kurikulum, disiplin pelajar dan perkembangan profesional. Di Malaysia, tugas sebagai pemimpin pertengahan di galas secara kebiasaannya oleh guru kanan mata pelajaran (GKMP). Tugas GKMP diadakan setelah terdapatnya proses pengagihan tanggungjawab dan autoriti pengetua bagi aspek pengajaran dan pembelajaran yang diwakilkan kepada pemimpin pertengahan (M. Anuar, Lokman \& M. Al-Muzammil, 2005).

\section{Komitmen Organisasi}

Menurut Mowday, Porter dan Steers (1982), komitmen organisasi dibahagikan kepada dua pemboleh ubah iaitu komitmen bermaksud kesungguhan yang dipamerkan oleh seseorang individu dalam mengidentifikasikan dirinya dalam organisasi dan melibatkan diri secara maksimum dalam organisasi tersebut. Komitmen terhadap organisasi dinyatakan sebagai bagaimana tahap komitmen yang diperlihatkan itu boleh dibuat pengukuran bagi organisasi di mana individu tersebut terlibat. Mereka turut berpendapat bahawa apabila seseorang pekerja mempunyai komitmen di tahap maksimum secara lumrahnya mereka dapat mengurangkan kadar lewat hadir bertugas, tukar ganti kerja, tidak hadir bertugas malah mampu meninggikan tahap kepuasan bertugas di dalam organisasi. Impak dari faktorfaktor ini diimplementasikan akan meningkatkan prestasi kerja dan pencapaian organisasi seterusnya komited untuk terus berada bersama organisasi sama ada secara langsung mahupun tidak langsung. Amalan budaya kerja seperti ini akan menyebabkan para staf akan sentiasa berusaha dengan gigih demi mencapai matlamat organisasi yang diinginkan.

Singh dan Billingsley (1998), dalam kajian mereka mendapati guru yang mempunyai komitmen terhadap organisasi mempunyai perkaitan yang sangat rapat dengan keberkesanan sekolah, pencapaian pelajar, prestasi kerja guru, kepuasan guru juga ketidakhadiran guru ke sekolah. Menurut Hussein (2005), guru dan komuniti yang mempunyai komitmen yang tinggi dilihat mampu melonjakkan pencapaian keberkesanan dan matlamat organisasi manakala A. Ghani (2009) menyatakan guru yang mempunyai komitmen yang rendah kebiasaannya akan meletakkan keutamaan kepada kepentingan diri berbanding melunaskan tanggungjawab dan tugas yang diamanahkan. Komitmen juga dirujuk sebagai satu situasi psikologi yang menurut individu kepada organisasi (Meyer \& Allen, 1997).

Mereka juga berpendapat bahawa komitmen terbahagi kepada 3 dimensi iaitu komitmen normatif, komitmen afektif dan komitmen berterusan. Menurut mereka lagi staf yang mempunyai komitmen yang tinggi akan mempunyai pandangan yang positif terhadap organisasi dan juga sama ada untuk meningkatkan persepsi diri yang positif ataupun mempamerkan sikap yang konsisten bagi menjauhi tanggapan negatif. Hasil kajian oleh Hulpia, Devos dan Rosseel (2009) terhadap perkaitan antara persepsi kepimpinan distributif guru dan kepimpinan guru terhadap kepuasan kerja dan komitmen terhadap organisasi telah mendapati bahawa penyelidik di dalam bidang kepimpinan distributif secara kekal tidak mengkaji hubungan di antara pemboleh ubah tersebut.

Pengagihan fungsi kepimpinan dikatakan terdapat hubungan yang lemah terhadap kepuasan kerja dan komitmen organisasi (Hulpia et al., 2009). Semakin penyeliaan disebarluaskan di dalam pasukan kepimpinan semakin menurun komitmen terhadap organisasi yang diperlihatkan oleh guru dan kepimpinan guru. Penglibatan guru di dalam membuat keputusan dilihat dapat melonjakkan komitmen guru di dalam organisasi. Hulpia et al. (2009) juga mengesahkan bahawa komitmen terhadap organisasi dapat dilihat dari jumlah sokongan terhadap kepimpinan guru dan kesepaduan pasukan kepimpinan serta mempunyai pertalian dengan kepuasan kerja guru. Hairudin dan Salisu (2015) dalam kajiannya juga mendapati terdapat impak yang besar antara komitmen guru dalam organisasi dengan 
kepimpinan distributif. Dapatan Hulpia, Devos dan Keer (2011) juga menyatakan bahawa terdapat hubungan yang signifikan di antara kepimpinan distributif dengan komitmen guru terhadap organisasi.

Mereka juga mendapati pengupayaan guru di kesan sebagai perantara yang kukuh dalam menentukan kepimpinan distributif dengan komitmen guru. Bogler dan Somech (2004) serta Gaziel (2009) turut memperolehi bahawa pengupayaan guru dapat ditingkatkan dengan penglibatan guru di dalam membuat keputusan malah ini dikesan dapat meningkatkan komitmen guru kepada organisasi (Bogler \& Somech, 2004).

\section{Iklim Sekolah}

Iklim sekolah didefinisikan sebagai situasi sekolah yang baik dengan keadaan persekitaran yang memberikan rasa tenteram, mesra, selesa, dan riang bersama pembelajaran yang lancar (Pusat Perkembangan Kurikulum, 1992). Menurut Bulach dan Malone (1994) kejayaan usaha- usaha kemajuan yang dijalankan di sekolah faktor penentunya adalah iklim sekolah yang positif. Ia juga bertindak sebagai usaha-usaha kepada penambahbaikan pencapaian pelajar (Freiberg, 1999). Kualiti persekitaran sekolah yang berlandaskan pengalaman disebabkan terdapatnya hubungan dengan iklim sekolah sehingga meninggalkan kesan terhadap tingkah laku bersandarkan kepada persepsi secara kolektif terhadap tingkah laku sekolah (Hoy dan Miskel, 1991).

Kenyataan ini turut disokong oleh Hoy dan Miskel (2005) yang menyatakan bahawa sesebuah organisasi dapat dibezakan dengan organisasi yang lain melalui iklim sekolah yang merupakan sebuah set kepada ciri-ciri dalaman seterusnya secara langsung ataupun tidak langsung mampu mempengaruhi tingkah laku ahli-ahli yang terdapat di dalam organisasi. Pencapaian pelajar yang positif juga dikatakan berpunca dari senario iklim sekolah yang positif juga dikatakan mempunyai pengaruh ke atas tingkah laku warga kerja di sesebuah organisasi (Goddard, Hoy, \& Woolfolk, 2000). Perintis kepada kajian yang berkaitan dengan iklim sekolah iaitu Halphin dan Croft (1963) mendapati iklim sekolah adalah gambaran yang merujuk kepada personaliti seseorang individu dan bagaimana guru berusaha dalam mendapatkan iklim sekolah yang berkesan ke atas organisasinya.

Hussien (1993) pula berpendapat bahawa iklim sekolah merupakan faktor dalaman institusi pendidikan yang meliputi pemboleh ubah sesuatu yang dapat dikecapi dan dinikmati oleh seseorang individu manakala Rechers dan Schneider (1990) pula memberi penerangan mengenai iklim organisasi pula merupakan amalan dan tatacara juga persepsi terhadap polisi yang dikongsi bersama malah individu memberikan penilai perihal ciri-ciri organisasi berasaskan nilai dan kepentingan ciri terhadap kesejahteraan mereka. Litwin dan Stringer (1968) pula berpendapat iklim organisasi mengandungi set sifat-sifat yang boleh diukur dari persekitaran kerja sama ada secara langsung atau tidak langsung dirasakan oleh individu yang bekerja di dalam persekitaran organisasi serta mampu mempengaruhi dan memotivasikan tingkah laku mereka. Davis dan Newstorm (2000) dalam kajian mereka mendapati untuk membuat pengukuran iklim organisasi terdapat tujuh unsur yang digunakan iaitu kualiti kepimpinan, komunikasi, kepercayaan, tanggung jawab, pengawalan, peluang dan imbuhan yang saksama . Menurut Tableman (2004), iklim sekolah terbahagi kepada 4 elemen persekitaran sekolah iaitu:

a) Persekitaran pembelajaran yang menggalakkan pengajaran dan pembelajaran.

b) Persekitaran fizikal yang memberi keselesaan dan menggalakkan pembelajaran.

c) Persekitaran afektif yang dapat menjana semangat kepunyaan dan aspek kendiri yang positif.

d) Persekitaran sosial yang menggalakkan komunikasi dan interaksi warganya.

Litwin dan Stringer (1968) menyatakan bahawa iklim organisasi mengandungi set sifat-sifat yang boleh diukur melalui persekitaran kerja sama ada secara langsung atau tidak langsung dirasakan oleh pekerja yang bekerja di dalam persekitaran organisasi yang mempengaruhi dan memotivasikan tingkah laku mereka.

\section{Kesimpulan}


Profesion guru menjadi lebih kompleks dan menuntut kekuatan psikologi guru yang pastinya menjadi kepentingan bagi fungsi guru yang optimum di tempat kerja iaitu sekolah, untuk sentiasa bermotivasi dan komited terhadap peranan profesional mereka. Oleh itu, terdapat lebih banyak keperluan penting bagi guru yang harus diberikan perhatian dalam mengembangkan pemerkasaan psikologi guru baik dalam program pengembangan keprihatinan dalam perkhidmatan, terutama dalam meningkatkan rasa makna, kompetensi, autonomi dan impak terhadap profesion guru. Apabila guru merasa berkepemimpinan dalam lingkungan kerja mereka dan dari pekerjaan yang mereka lakukan, mereka cenderung merasa puas dengan pekerjaan mereka dan komited terhadap organisasi dan profesion mereka.

\section{Rujukan}

Abdul Ghani Kanesan. (2009). Pengaruh Kepemimpinan Transformasi Sekolah dan Efikasi Kolektif Guru Terhadap Komitmen Kualiti Pengajaran. Prosiding Seminar Nasional Pengurusan dan Kepimpinan ke16. Institut Aminuddin Baki, Genting Highlands.

Agsita Lara \& Safitri Garnis. (2018). Pengaruh Iklim Organisasi Terhadap Komitmen Organisasi Karyawan Generasi Y PT. Indomarco Prismatama Kota Semarang. Fakultas Psikologi. Universitas Sanata Dharma, 1-84.

Ai Noi Lee \& Youyan Nie. (2014). Understanding Teacher Empowerment: Teachers' Perceptions Of Principal's And Immediate Supervisor's Empowering Behaviours, Psychological Empowerment And Work-Related Outcomes. Psychological Studies Academic Group, 41,67-79

Azhar, H., Ramli, B., Zaidatol, A., Lope, P., Soaib, A. (2016). Hubungan Antara Amalan Kepimpinan Distributif Pengetua dan Kepimpinan Guru di Sekolah Menengah. International Journal of Education And Tranining (INJET), 2(2), 1-3.

Bandura, A. (1986). Social Foundations Of Thought and Action: A social Cognitive Theory. Englewood Cliffs, NJ: Prentice Hall.

Bass, B., M. (1990). Bass \& Stogdill's Handbook Of Leadership. Theory, Research and Managerial Applications. (3rd ed.). New York: Collier Macmillan Publishers.

Bennis, W., \& Nanus, B. (1985). Leaders: The Strategies For Taking Charge. New York: Harper \& Row.

Blandford, S. (2004). Panduan Pengurus Peringkat Pertengahan di Sekolah. Edisi Terjemahan Oleh Bahariah Yusuf. Kuala Lumpur: Institut Terjemahan Negara Malaysia Berhad.

Bogler, R., \& Somech, A. (2004). Influence Of Teacher Empowerment On Teachers' Organizational Commitment, Professional Commitment And Organizational Citizenship Behavior In Schools. Teaching and Teacher Education, 20, 277-289.

Bolden, R. (2007). Distributed Leadership. Discussion Paper In Management, 07(02), 1-8.

Bolden, R. (2011). Distributed Leadership In Organisations: A Review of Theory and Research. International Journal of Management Reviews, 13, 251- 269.

Botha, R., \& Triegaardt, P. (2014). Distributive Leadership as Management Strategy For School Effectiveness: The Place and Role of the OSCAR Coaching Model in South African Schools. Journal of Social Sciences, 40, 251-260.

Bulach, C., R., \& Malone, B. (1994). The relationship of school climate to the implementation of school reform. ERIC SPECTRUM, 12(4), 3-8.

Bush, T. (2001). Middle Level Leader Thinkpiece. National Collenge for School Leadership. Retrieved from: http://www.ncsl.onlink.

Cohen, J., McCabe, E., M., Michelli, N., M., \& Pickeral, T. (2009). School Climate: Research, Policy, Teacher Education And Practice. Teachers College Record, 111(1), 180-213.

Danielson, C., F. (2007). The Many Faces of Leadership. Educational Leadership, 65, 14-19.

Davis, K., \& Newstorm, J. ( 2004). Kelakuan dalam Organisasi. (7th ed.). Jakarta: Erlangga.

Dee, J., R., Henkin, A., B., \& Duemer, L. (2003). Structural Antecedents And Psychological Correlates Of Teacher Empowerment. Journal of Educational Administration, 41(3), 257-277.

DeMatthews, D. (2014). Principal and Teacher Collaboration: An Exploration of Distributed Leadership in Professional Learning Communities. International Journal of Educational Leadership and Management, 2(2), 176-206. 
Dinham, S., Aubusson, P., \& Brady, L. (2006). Distributed Leadership Through Action Learning, Keynote Address. Fifth International Conference on Educational Leadership. Australian Centre for Educational Leadership. University of Wollongong. 16 - 17 February

Erawan, P. (2008). Teacher Empowerment And Developing A Curricular Management System In Municipal Schools Using Cooperation Between University And Municipality in Thailand. Asia Pacific Journal of Education, 28(2), 161-176.

Fiedler, F., E. (1967). A Theory Of Leadership Effectiveness. New York:McGraw-Hill Book Company.

Freibergh, H., J. (1999). School Climate: Measuring, Improving, and Sustaining Healthy Learning Environments. Falmer Press, Philadelphia, PA.

Gaziel, H. (2009). Teacher empowerment and commitment at school based and non school based sites, In Zadja, J. And Gamage, D.T. (eds.). Decentralization school based management and quality, globalization, comparative education and policy research 8. Springer Science and Business Media $\mathrm{BV}$

Ghani, N., Hussin, T., \& Jusoff, K. (2009). The Impact Of Psychological Empowerment On Lecturers' Innovative Behaviour In Malaysian Private Higher Education Institutions. Canadian Social Science, 5(4), 54-62

Goddard, R., D., Hoy, W., K., \& Woolfolk Hoy, A. (2000) Collective Efficacy: Its Meaning, Measure, and Impact on Student Achievement. American Educational Research Journal, 37, 479-507.

Gordon, R., D. (2010). Dispersed Leadership: Exploring The Impact Of Antecedent Forms Of Power Using A Communicative Framework. Management Communication Quarterly, 24, 260-287.

Hairuddin, M. A. \& Salisu, A. Y. (2015). Distributed leadership and empowerment influences on teachers' organizational commitment. Academic Journal of Interdisciplinary Studies, 4(1), 73-84.

Halpin, A., W., \& Croft, D., B. (1963). The Organizational Climate of Schools. Chicago, IL: Midwest Administration Center of the University of Chicago.

Halverson, R. (2007). Systems Of Practice and Professional Community: The Adams Case. In J. P. Spillane (Ed.), Distributed Leadership In Practice. New York: Teachers College Press.

Harris, A. (2002). Effective Leadership In School Facing Challenges Contexts. Paper Presented At The American Research Association Conference, New Orleans.

Harris, A. (2004). Distributed Leadership And School Improvement: Leading Or Misleading Educational Management Administration \& Leadership. London: SAGE Publication.

Harris, A., \& Muijs, D. (2004). Improving Schools through Teacher Leadership. London: Oxford University Press.

Harris, A., \& Spillane, J. (2008). Distributed Leadership Through The Looking Glass. Management in Education, 22,31-34.

Harris, A. (2012). Distributed Leadership: Implications For The Role Of The Principal. Journal of Management Development, 31(1), 7-17.

Hollander, E., P. (1979). Leadership and Social Exchange Processes. In K. Gegen, M S. Greenberg, and R. H. Willis (Eds.). Social Exchange: Advances In Theory and Research, New York: Winston-John Willey

Hoy, W. K., \& Miskel, C. G. (1991). Educational administration: Theory, research and practice. New York: McGraw-Hill, Inc.

Hoy, W., K., \& Miskel, C., G. (2005). Educational Administration: Theory, Research, and Practice. New York: McGraw- Hill.

Hoy, W., K., \& Miskel, G., C. (2012). Educational Administration, Theory, Research and Practice (7th ed.). (Translation Editor: Selahattin Turan). Ankara: Nobel Publications.

Hulpia, H., Devos, G., \& Rosseel, Y. (2009). The Relationship Between The Perception of Distributed Leadership in Secondary Schools and Teachers' and Teacher Leaders' Job Satisfaction and Organizational Commitment. School Effectiveness and School Improvement, 20(3), 291-317.

Hulpia, H., Devos, G., \& Keer, H., V. (2011). The relation between school leadership from a distributed perspective and teachers' organizational commitment: Examining the source of the leadership function. Educational Administration Quarterly, 47(5), 728- 771.

Hussein Mahmud. (1993). Kepemimpinan Keberkesanan Sekolah. Kuala Lumpur: DBP.

Hussein Mahmood. (2005). Kepemimpinan Profesionalisme: Satu Utopia? Pemimpin, 5, 39-51.

Hussein Ahmad. (2012). Mission Of Public Education In Malaysia: The Challenge Of Transformation. Kuala Lumpur: University of Malaya Press. 
Jaros, S. (2010). Commitment to Organizational Change: A Critical Review. Journal of Change Management, 10, 79-108.

Kelly, R., C., Thornton, B., \& Daughherty, R. (2005). Relationship Between Measures Of Leadership And School Climate. Education, 126(1), 17-25.

Kouzes, J. M., \& Posner, B. Z. (2003). Exemplary leadership. San Francisco: CA: Jossey-Bass Publishers.

Kementerian Pelajaran Malaysia, KPM (2013). Laporan Awal-Ringkasan Eksekutif: Pelan Pembangunan Pendidikan Malaysia 2013-2025.

Lee, J., C., Yin, H., Zhang, Z., \& Jin, Y. (2011). Teacher Empowerment And Receptivity In Curriculum Reform In China. Chinese Education and Society, 44(4), 64-81.

Leithwood, K., \& Jantzi, D. (1999). Transformational School Leadership Effects: A Reproduction. School Effectiveness And School Improvement, 10(4), 451-479.

Leithwood, K., and Jantzi, D. (2000). The effects of different sources of leadership on student engagement in school. In Riley, K. and Louis, K. (eds), Leadership for Change and School Reform. London: Routledge, pp. 50-66.

Levin, B., \& Fullan, M. (2008). Learning about System Renewal. Educational Management Administration \& Leadership, 36(2), 289-303.

Litwin, G., H., \& Stringer, R., A. (1968). Motivation and organizational climate. Boston: Division of Research, Graduate School of Business Administration, Harvard University.

Louis, K., S., Mayrowetz, D., Smiley, M. and Murphy, J. (2009). The Role Of Sense Making and Trust In Developing Distributed Leadership. In Harris, A. (ed.), Distributed Leadership. Dordrecht: Springer, 157-180.

Malloy, J., P. (2012). Effects Of Distributed Leadership On Teachers'Academic Optimism and Student Achievement. Department of Theory and Policy Studies Ontario Institute for Studies in Education of the University of Toronto, 1-93.

Marlia, J.,Yahaya, D. (2016). Praktis Kepimpinan Distributif dan Komitmen Terhadap Organisasi Berdasarkan Kohort Generasi Guru. International Seminar on Generating Knowledge Through Research, 275-286.

Meyer, J., P., \& Allen, N., J. (1997). Commitment In The Workplace: Theory, Research and Application, Thousands.

Mohd Anuar Abdul Rahman, Lokman Mohd Tahir \& M. Al Muzammil (2005). Komitmen dan Prestasi Ketua Panitia Dalam Kerja Berpasukan. Retrieved from: www.iab. edu. my/sn16/Dr Anuar.pdf.

Mowday, R.T., Porter, L.W. \& Steers, R. (1982). Employee-Organizational Linkages: The Physcology of Commitment, Absenteeism, and Turnover. New York: Academic Press.

Muijs, D., \& Harris, A. (2003). Teacher Leadership - Improvement Through Empowerment? An Overview Of The Literature. Educational Management \& Administration, 31(4), 437-448.

Newman, M., \& Simmons, W. (2000). Leadership For Student Learning. Phi Delta Kappan, 82(1), 912.

Neves, P. (2011). Building commitment to change: The role of perceived supervisor support and competence. European Journal of Work and Organizational Psychology, 20, 437- 450.

Ofsted. (2000). Improving City Schools. London: Office for Standard in Education.

Owens \& Robert, G. (1991). Organizations Behaviour in Education. Boston, Mas: Allyn and Bacon.

Pearce, C., L., \& Manz, C., C. (2005). The New Silver Bullets of Leadership: The Importance of Selfand Shared Leadership in Knowledge Work. Organizational Dynamics, 34(2), 130-140.

Pearce, C., L., \& H., P., \& Sims Jr. (2002). Vertical Versus Shared Leadership as Predictors of the Effectiveness of Change Management Teams: An Examination of Aversive, Directive, Transactional, Transformational, and Empowering Leader Behaviors. Group Dynamics: Theory, Research, and Practice, 6(2), 172-197.

Pusat Perkembangan Kurikulum. (1992). Buku Penerangan Kurikulum Bersepadu Sekolah Menengah. Kementerian Pendidikan Malaysia: Kuala Lumpur.

Reichers, A., E., \& Schneider, B. (1990). Climate and culture: An evolution of constructs. In B. Schneider (Ed.), Organizational climate and culture, 5-39.

Richard, L. Daft. (2008). The Leadership Experience. United State Of America: Thomson SouthWestern. (4th ed.). 
Sergiovanni, T., J. (2000). The Lifeworld of Leadership: Creating Culture, Community, And Personal Meaning In Our Schools. San Francisco, CA: Josey-Bass Publishers.

Short, P., M., \& Rinehart, J., S. (1992). School Participant Empowerment Scale: Assessment Of Level Of Empowerment Within The School Environment. Journal of Educational And Psychological Measurement, 52, 951-960.

Silins, H., and Mulford, W. (2002). Leadership and school results. In Leithwood, K. and Hallinger, P. (eds), Second International Handbook of Educational Leadership and Administration. Dordrecht: Kluwer, pp. 561-612.

Singh, K., \& Billingsley, B., S. (1998). Professional Support and Its Effects On Teachers' Commitment. The Journal of Educational Research, 91(4),229-239.

Smith, S., C., \& Piele, P., K., (Eds.). (1997). School Leadership. Handbook For Excellence. Eugene, OR: ERIC Clearinghouse on Educational Management.

Smylie, M., A., \& Brownlee-Conyers, J. (1992). Teacher Leaders and Their Principals: Exploring The Development Of New Working Relationships. Educational Administration Quarterly, 28,150184.

Spillane, J., P., Halverson, R., \& Diamond, J. (2004). Towards A Theory Of Leadership Practice: A distributed perspective. Journal of Curriculum Studies, 36, 3-34.

Spillane, J., P. (2006). Distributed Leadership. San Francisco, CA: Jossey-Bass.

Tableman, B. (2004). Best Practice Briefs. Michigan State University.

Troen, V., \& Boles, K. (1993). Teacher leadership. Education Week, 11(3), 27-29.

Wan, E. (2005). Teacher Empowerment: Concepts, Strategies, And Implications For Schools In Hong Kong. Teachers College Record, 107(4), 842-861.

Watson, S., T., \& Scribner, J., P. (2007). Beyond distributed leadership: Collaboration, interaction, and emergent reciprocal influence. Journal of School Leadership, 17(4), 443-468.

Wise, C. (2001). The Monitoring Role Of Academic Middle Manager In Secondary Schools. Educational Management \& Administration, 29(3), 333-341.

Woods, P. (2004). Democratic leadership: drawing distinctions with distributed leadership. International Journal of Leadership in Education, 7, 3-26.

Woods, P., A. \& Gronn, P. (2009). Nurturing Democracy: The Contribution Of Distributed Leadership To A Democratic Organizational Landscape. Educational Management Administration and Leadership, 37,430-451.

Yaakob, D., Zuraidah, J., M., Y., Rozalina, K., Yahya D., M., S. Omar, F., Arumugam, R., \& Fauzi, H. (2015). Distributive Leadership Among Leaders In Effective Schools. Journal Of Teaching \& Education, 4(3), 423-433.

Yukl, G. (1999) An Evaluation of Conceptual Weaknesses in Transformational and Charismatic Leadership Theories. The Leadership Quarterly, 10(2), 285-305.

Zembylas, M., \& Papanastasiou, E., C. (2005). Modeling Teacher Empowerment: The Role Of Job Satisfaction. Educational Research And Evaluation: An International Journal On Theory and Practice, 11(5), 433-459. 